\title{
Formation of 3,3,4-Trimethyl-1,7-dibromonorbornane-2-one: a Spectroscopic and Computational Study
}

\author{
Ingrid T. Sabbagh and Perry T. Kaye* \\ Department of Chemistry, Rhodes University, Grahamstown, South Africa.
}

Received 25 June 2019, revised 20 November 2019, accepted 11 December 2019.

\section{ABSTRACT}

The structure and origin of the major by-product in the synthesis of 8-bromocamphor from $(+)-3,3,8$-tribromocamphor has been confirmed using NMR, coset and single crystal X-ray analysis and DFT-level computational techniques.

\section{KEYWORDS}

Camphor derivatives, skeletal rearrangement, DFT calculations, NMR, coset analysis.

\section{Introduction}

In our research on the development of multidentate ligands for the construction of ruthenium complexes as novel metathesis catalysts, ${ }_{1}^{1}$ we have targeted the $\mathrm{D}$ - $(+)$-camphor $(\mathbf{1})$-derived, tridentate ligand 2 in the expectation that coordination with ruthenium would afford the chelated analogue 4 of the first-generation Grubbs catalyst 3. ${ }^{2}$ Application of the method reported by Money and co-workers ${ }^{3-6}$ afforded the critical precursor, 8-bromocamphor 5, in $33 \%$ overall yield from (+)-3-endo-bromocamphor 6. In the final step [a $\mathrm{Zn} \mathrm{dust/}$ AcOH-mediated reaction of (+)-3,3,8-tribromocamphor 8] in the synthesis of this precursor, we isolated the desired product 5 in $44 \%$ yield together with the major by-product, 3,3,4-trimethyl1,7-dibromonorbornane-2-one 10, in $10 \%$ yield (Scheme 1). In this communication, we discuss the characterisation of 3,3,4trimethyl-1,7-dibromonorbornane-2-one $\mathbf{1 0}$ and the use of DFT calculations to resolve conflicting mechanistic explanations for its formation.

One- and two-dimensional NMR spectroscopy of a byproduct isolated during the synthesis of $(+)$-8-bromocamphor 5 appeared to be consistent with $(1 R, 4 S)-3,3,4$-trimethyl-7,7-
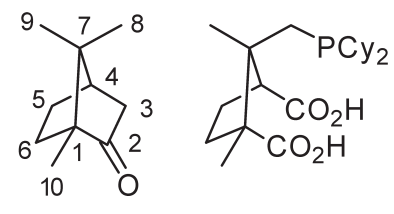

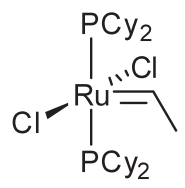
3
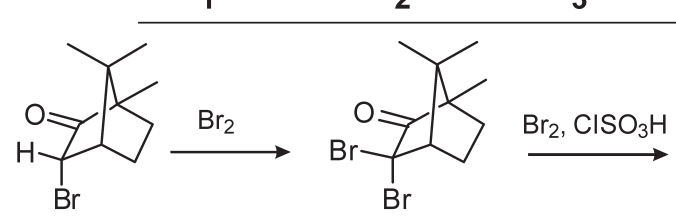

7 dibromonorbornan-2-one 9. It was assumed that the by-product is formed during the reaction of the dibromo compound 7, but the results of a $\operatorname{coset}^{7}$ analysis of possible rearrangement pathways from 3,3-dibromocamphor 7 to compound 9 challenged this structural assignment.

In the coset analysis the maximum number of rearrangement steps in a given sequence was limited to 13 and the permissible operations to: Wagner-Meerwein rearrangements (WM), 2,3-exo- (23x), 2,3-endo- (23e) and 6,2- (62) shifts. Within these limits, the analysis generated the four potential pathways summarised in Fig. 1 for formation of compound 9 (in its protonated form $9 \mathrm{H}^{+}$) from the protonated dibromocamphor starting material $7 \mathrm{H}^{+}$; the rearrangement was expected to be acid-catalysed, thus warranting the use of protonated species.

The shortest sequence, the 7-step pathway (1) outlined in Scheme 2, commences with a Wagner-Meerwein rearrangement, followed by a 2,3-endo-methyl shift, a second WagnerMeerwein and a 2,3-endo-bromide shift to afford intermediate iv. However, neither of the two subsequent steps, viz. the 2,3-exo-hydride shift to intermediate $\mathbf{v}$ nor the 2,3-endo-bromide shift to the gem-dibromide species vi, would be expected to be

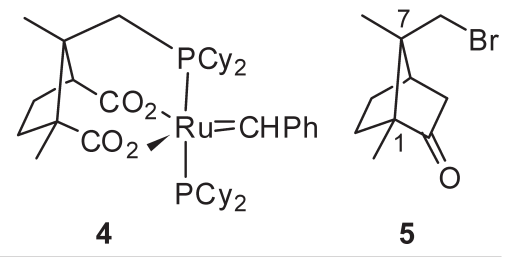<smiles>CC12CCC(C(Br)(Br)C1=O)C2(C)CBr</smiles>
$\mathrm{Zn}, \mathrm{CH}_{3} \mathrm{COOH}$<smiles>CC12CCC(CC1=O)C2(C)CBr</smiles>

8 5

Possible structures isolated by-product
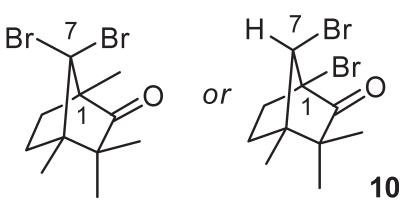

Scheme 1 


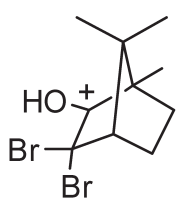

$7 \mathrm{H}+$
1. WM 23e WM 23e $23 x 23$ e WM

2. 23 e $23 \times 23$ e 62 WM 62 WM 62

3. $23 x$ 23e $23 x 62$ WM 62 WM 62

4. 62 WM 23e WM 23e WM 62 WM 62<smiles>CC1(C)[C@H](O)[C@H]2CC[C@@]1(Br)C2(Br)Br</smiles>

$9 \mathrm{H}+$
WM = Wagner-Merwein

$23 e=2,3$-endo shift

$23 x=2,3$-exo shift

$62=6,2$ shift

Figure 1 Potential rearrangement pathways (1-4) for the formation of $9 \mathrm{H}^{+}$from $7 \mathrm{H}^{+}$.

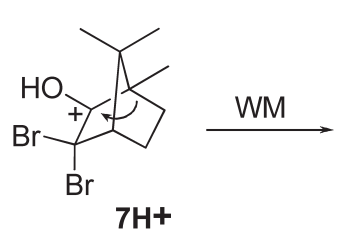

7H+<smiles>CC1(C)[C@H](O)[C@@H]2CC[C@]1(Br)C2(C)C</smiles>

$9 \mathrm{H}+$<smiles>CC1(C)CC2(Br)CCC1C2(C)C</smiles>

i

$23 e$<smiles>OC1(Br)C2CCCC(C2)C1(Br)Br</smiles>

ii<smiles>CC1(C)C2(O)CCC1(Br)C(Br)(Br)[C+]2Br</smiles>

$23 e$<smiles>CC1(C)C(F)(Br)C2CCC1(O)C2Br</smiles>

$23 x$

Scheme 2 Shortest coset sequence for the rearrangement of protonated structures $7 \mathrm{H}^{+}$to $9 \mathrm{H}^{+}$.

energetically favoured. The 2,3-exo-hydride shift, while not impossible, is not likely to result in the relief of steric strain or the generation of a more highly substituted carbocation, while the 2,3-endo-bromide shift leads to the more sterically hindered species vi.

An examination of the alternative routes (2-4) to the cationic species $\mathbf{9} \mathbf{H}^{+}$(Fig. 1) revealed the same energetically unfavourable hydride and bromide shifts in each pathway. These observations raised doubt concerning the assignment of structure 9. Money and co-workers ${ }^{3-6}$ had also isolated a by-product to which they assigned structure 10 using ${ }^{1} \mathrm{H}$ NMR data; this was subsequently supported by X-ray crystallographic analysis. ${ }^{11}$ Re-examination of our one- and two-dimensional NMR data confirmed their consistency with structure 10. Thus, the ${ }^{1} \mathrm{H}$ NMR spectrum clearly indicates the presence of: three methyl singlets at 1.08, 1.23 and 1.39 ppm; multiplets characteristic of the 5- and 6-methylene groups; and a singlet at 4.22 ppm corresponding to the relatively deshielded 7-methine proton. The ${ }^{13} \mathrm{C}$ NMR spectrum revealed the requisite number of methine, methylene, methyl, quaternary and carbonyl carbon signals, while the HMQC and HMBC data confirmed the proton-carbon connectivities - all of which, superficially at least, are also consistent with structure 9! Single crystal X-ray analysis of the byproduct isolated in our study ${ }^{12}$ confirmed it to be the same as the compound isolated previously by Money and co-workers, ${ }^{5}$ viz. 3,3,4-trimethyl-1,7-dibromonorbornan-2-one $\mathbf{1 0}$ and not the isomeric system 9.

There remains, however, some disagreement about the mechanistic pathways followed in the transformation of 3,3-dibromocamphor 7 to the by-product 10. Money and co-workers had proposed $^{5}$ that 3,3,4-trimethyl-1,7-dibromonorbornan-2-one 10 was formed from the protonated intermediate $7 \mathrm{H}^{+}$via the Wagner-Meerwein rearrangements, and the 2,3-endo-methyl and 2,3-exo-bromide shifts illustrated in Pathway I (Scheme 3). Antkowiak and Antkowiak, ${ }^{13}$ on the other hand, argued that the Wagner-Meerwein shift from intermediate 12 to intermediate $\mathbf{1 3}$ was not feasible unless the carbon attached to the cationic centre bears two bromine atoms, as in structure 16, reasoning that the steric effect of the dibromomethyl group renders the
Wagner-Meerwein rearrangement $\mathbf{1 6} \rightarrow \mathbf{1 7}$ energetically preferable to the competing 2,3-methyl shift (as in the monobromomethyl case $15 \rightarrow 20$ ). Consequently, they favoured Pathway II, in which compound $\mathbf{1 0}$ is formed as an intermediate during the final $\mathrm{Zn}$ dust/AcOH-mediated reaction of compound 19 which leads to 8-bromocamphor 5 and 3,3,4-trimethyl-1,7-dibromonorbornan-2-one 10. Pathway III leads to the formation of 8-bromocamphor 5 from the intermediate $\mathbf{1 5}$, as explored in our earlier paper. ${ }^{2}$

In order to explore the competing mechanistic proposals, we conducted a modelling study using the Accelrys $\mathrm{DMol}^{3}$ DFT code in Materials Studio. Stable ground state structures could not be generated for either of the intermediates 13 or 14 in Pathway I. However, stable structures were located for the intermediates $\mathbf{1 6}$ and $\mathbf{1 8}$ in Pathway II. These species appear to be linked by a single transition state with a relatively low activation energy $\left(7.59 \mathrm{kcal} \mathrm{mol}^{-1}\right)$, implying that the Wagner-Meerwein rearrangement $(\mathbf{1 6} \rightarrow \mathbf{1 7})$ and the 2,3-exo-bromide shift $(\mathbf{1 7} \rightarrow \mathbf{1 8})$ are, in fact concerted. This transformation is detailed in Scheme 4, in which the transition state TSI approximates in structure to the tetrabromo intermediate 17. An energetically favourable Wagner-Meerwein rearrangement of intermediate 18 then affords the tetrabrominated species 19 via a second transition state TSII (Scheme 5). The computational data for Pathway II are summarised in Table 1 and illustrated in Fig. 2.

In our synthesis of 8 -bromocamphor 5 , there was no spectroscopic evidence for the presence of the by-product $\mathbf{1 0}$ in the reaction mixture until after the final, $\mathrm{Zn}$ dust/AcOH-mediated reaction step. Both the computational and experimental evidence thus indicate Pathway II, as proposed by Antkowiak and Antkowiak, ${ }^{13}$ to be a more likely route to compound 10 than

Table 1 DFT reaction energies $\left(\mathrm{kcal} \mathrm{mol}^{-1}\right)$ for the rearrangements depicted in Pathway II (Scheme 3).

\begin{tabular}{lcccc}
\hline Reaction & $\Delta \mathrm{E}$ & $\mathrm{E}_{\mathrm{a}}$ & $\Delta \mathrm{G}_{298}$ & $\Delta \mathrm{G}_{298}^{\ddagger}$ \\
\hline $\mathbf{1 6} \rightarrow \mathbf{1 8}$ & -4.02 & 8.39 & -5.06 & 7.59 \\
$\mathbf{1 8} \rightarrow \mathbf{1 9}$ & -25.75 & 2.78 & -24.75 & 2.45 \\
\hline
\end{tabular}




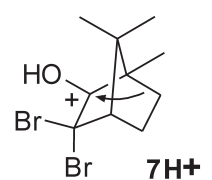

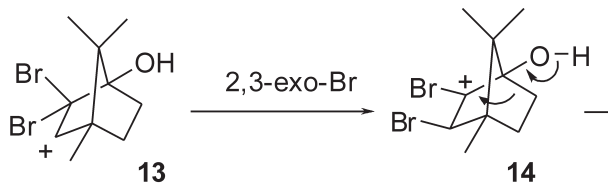<smiles>CC1(C)C(=O)C2(Br)CCC1(C)C2Br</smiles>

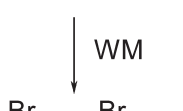<smiles></smiles><smiles>CC1(C)C2CCC(O)(C2(C)C)C1(Br)Br</smiles>

Pathway I<smiles>Br[Mg]Br</smiles>

WM<smiles>CC12C(O)C(Br)(CCC1(Br)C(Br)Br)C2Br</smiles><smiles>CC1(C)[C@H]2CC[C@@](C)(C2(C)C)C1(Br)Br</smiles>

12

\section{Pathway II}<smiles>CC1(C)[C@H](CBr)CC[C@H]1CBr</smiles>

15<smiles>CC1(C)[C@@H]2CC[C@@](Br)([C@@H]1Br)C(Br)(Br)C2(C)C</smiles>

16<smiles>CC1(C)C2(O)CCC(Br)(C(Br)Br)C(Br)(Br)C1(Br)C2Br</smiles>

17<smiles>CC1(C)C2(O)CCC1(C(Br)Br)C(Br)C2Br</smiles>

18

2,3-endo-Me<smiles>CC1(C)C(Br)(Br)C2(CBr)CCC1(C)C2(C)CBr</smiles>

20

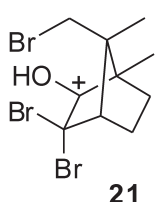

21

\section{Pathway III}

Scheme 3 Mechanistic pathways previously proposed for the transformation of 3,3-dibromocamphor 7 to the by-product 10

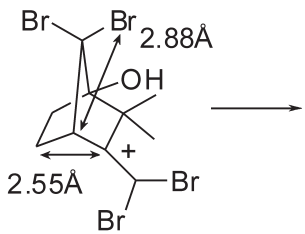

16

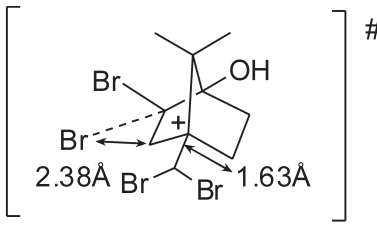

TSI

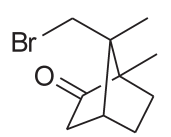

Scheme 4 Transformation $16 \rightarrow 18$, showing significant inter-nuclear distances.

Pathway I, as suggested by Money and co-workers. ${ }^{5}$ A combination of techniques, including coset, advanced one- and twodimensional NMR and theoretical analysis, has thus permitted confirmation of the structure of a minor, terpenoid rearrangement product $\mathbf{1 0}$ and provided support for a mechanism involved in its formation.

\section{Experimental}

\subsection{General}

NMR spectra were recorded on a Bruker AVANCE $400 \mathrm{MHz}$ spectrometer at $303 \mathrm{~K}$ in $\mathrm{CDCl}_{3}$, and calibrated using solvent signals. Infrared spectra were recorded on a Perkin Elmer FT-IR

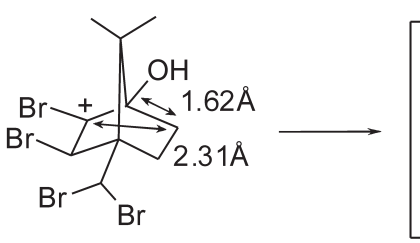

18

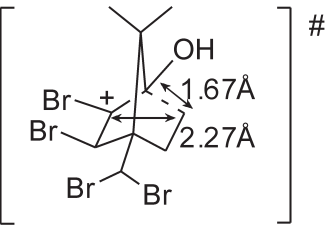

TSII

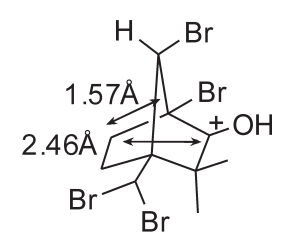

19

Scheme 5 Transformation $18 \rightarrow$ 19, showing significant inter-nuclear distances. 




Figure 2 Free energy diagram for Pathway II (16 $\rightarrow \mathbf{1 9}$; Scheme 3). The gas-phase free-energies are presented in brackets.

Spectrum 2000 spectrometer. Low-resolution (EI) mass spectra were obtained on a Finnigan-Mat GCQ mass spectrometer. Optical rotations were measured on a Perkin Elmer 141 polarimeter using a $1 \mathrm{dm}$ cell, with concentrations cited in g $100 \mathrm{~mL}^{-1}$. Optically pure compounds were derived from commercially available, homochiral, $(1 R)-(+)$-camphor.

\section{(+)-8-Bromocamphor 5 and (-)-3,3,4-Trimethyl-1,7-dibromo- norbornan-2-one $\mathbf{1 0}^{3-5}$}

(+)-3,3,8-Tribromocamphor $8(8.0 \mathrm{~g}, 20 \mathrm{mmol})$ was dissolved in glacial acetic acid $(40 \mathrm{~mL})$ in a round-bottomed flask. Zinc dust $(4.4 \mathrm{~g})$ was added, and the reaction mixture stirred vigorously while being cooled with ice-water. Stirring was continued for $1 \mathrm{~h}$, during which time the exothermic reaction subsided. The solution was then decanted from the zinc salt into $\mathrm{Et}_{2} \mathrm{O}$ (ca. $300 \mathrm{~mL}$ ), and the resulting mixture was washed with water $(10 \times 50 \mathrm{~mL})$ and dried over anhydrous $\mathrm{MgSO}_{4}$. Removal of the solvent in vacuo afforded a brown oil $(9.7 \mathrm{~g})$ which was chromatographed [flash chromatography on silica gel; elution with hexane-EtOAc (9:1)] to afford two fractions.

i) (+)-8-Bromocamphor 5 (44\%)

An analytical sample was prepared by further chromatography [HPLC on Partisil 10; elution with hexane-EtOAc (9:1)], affording white crystals of (+)-8-bromocamphor 5, m.p. 82-84 ${ }^{\circ} \mathrm{C}$ (lit., $\left.{ }^{3} 83-85^{\circ} \mathrm{C}\right) ;[\alpha]_{\mathrm{D}}^{22}=+72.5^{\circ}\left(c \quad 0.80, \mathrm{CHCl}_{3}\right),\left\{\right.$ lit., $^{3}[\alpha]_{\mathrm{D}}^{25}=$ $\left.+76.7^{\circ}\left(c 1.24, \mathrm{CHCl}_{3}\right)\right\} ; \delta_{\mathrm{H}}\left(400 \mathrm{MHz} ; \mathrm{CDCl}_{3}\right) 0.92\left(3 \mathrm{H}, \mathrm{s}, 9-\mathrm{CH}_{3}\right)$, $1.14\left(3 \mathrm{H}, \mathrm{s}, 10-\mathrm{CH}_{3}\right), 1.38(1 \mathrm{H}, \mathrm{m}, 5-\mathrm{H}), 1.56(1 \mathrm{H}, \mathrm{m}, 6-\mathrm{H}), 1.81(1 \mathrm{H}$, $\mathrm{m}, 6-\mathrm{H}), 1.91(1 \mathrm{H}, \mathrm{m}, 5-\mathrm{H}), 1.95(1 \mathrm{H}, \mathrm{d}, J 18.4 \mathrm{~Hz}, 3-\mathrm{H}), 2.39(1 \mathrm{H}, \mathrm{m}$, $3-\mathrm{H}), 2.44(1 \mathrm{H}, \mathrm{t}, J 4.4 \mathrm{~Hz}, 4-\mathrm{H}), 3.10(1 \mathrm{H}, \mathrm{d}, J 11.0 \mathrm{~Hz}, 8-\mathrm{H})$ and 3.17 $(1 \mathrm{H}, \mathrm{d}, J 11.0 \mathrm{~Hz}, 8-\mathrm{H}) ; \delta_{\mathrm{C}}\left(100 \mathrm{MHz} ; \mathrm{CDCl}_{3}\right) 9.4(\mathrm{C}-10), 15.6(\mathrm{C}-9)$, 26.3 (C-5), 31.8 (C-6), 39.5 (C-8), 41.4 (C-4), 42.4 (C-3), 51.5 (C-1), $58.2(\mathrm{C}-7)$ and $217.8(\mathrm{C}-2) ; \mathrm{m} / \mathrm{z} 230 / 232\left(\mathrm{M}^{+}, 57 \% / 55 \%\right)$ and 107 (100).

ii) (1S,4S,7R)-3,3,4-Trimethyl-1,7-dibromonorbornan-2-one 10 $10 \%$, m.p. $117-119$ C (lit., ${ }^{3} 123-124{ }^{\circ} \mathrm{C}$ ); $\mathrm{n}_{\max }$ (thin film) $/ \mathrm{cm}^{-1}$ $1761(\mathrm{C}=\mathrm{O}) ;[\alpha]_{\mathrm{D}}^{23}=-53.3^{\circ}$ (c $\left.1.05, \mathrm{CHCl}_{3}\right)\left\{\right.$ lit., ${ }^{3}[\alpha]_{\mathrm{D}}^{23}=-51.5^{\circ}$ (c 1.57, $\left.\left.\mathrm{CHCl}_{3}\right)\right\} ; \delta_{\mathrm{H}}\left(400 \mathrm{MHz} ; \mathrm{CDCl}_{3}\right) 1.08\left(3 \mathrm{H}, \mathrm{s}, 9-\mathrm{CH}_{3}\right), 1.23$ $\left(3 \mathrm{H}, \mathrm{s}, 8-\mathrm{CH}_{3}\right), 1.39\left(3 \mathrm{H}, \mathrm{s}, 10-\mathrm{CH}_{3}\right), 1.68-1.74(1 \mathrm{H}, \mathrm{m}, 5-\mathrm{H})$, 2.09-2.12 (1H, m, 6-H), 2.12-2.15 (1H, m, 5-H), 2.29-2.32 (1H, m,
6-H) and $4.22(1 \mathrm{H}, \mathrm{s}, 7-\mathrm{H}) ; \delta \mathrm{C}\left(100 \mathrm{MHz} ; \mathrm{CDCl}_{3}\right) 15.8$ (C-8), 23.4 (C-10), 24.6 (C-9), 31.9 (C-5), 33.5 (C-6), 47.5 (C-4), 47.9 (C-3), 65.2 (C-7), $71.6(\mathrm{C}-1)$ and $210.7(\mathrm{C}-2) ; \mathrm{m} / \mathrm{z} 308(\mathrm{M}+, 4 \%)$ and $159(100)$.

\subsection{Computational Methods}

Density functional calculations were conducted using the Accelrys DMol ${ }^{3}$ DFT code in Materials Studio (version 2.2) (14 $^{14}$ on LINUX-based Pentium IV PCs. All calculations involved use of the generalized gradient approximation (GGA) functional by Perdew and Wang (PW91) ${ }^{15}$ and the double numerical plus polarization' (DNP) basis set: a polarized split valence basis set of numeric atomic functions which are exact solutions to the Kohn-Sham equations for the atoms. ${ }^{16}$ Geometry optimizations were subjected to convergence criteria of threshold values $2 \times$ $10^{-5} \mathrm{Ha}, 0.004 \mathrm{Ha} / \AA, 0.005 \AA$ and $1 \times 10^{-5} \mathrm{Ha}$ for energy, force, displacement and self-consistent field (SCF) density, respectively. All calculations employed a method based on Pulay's $\mathrm{s}^{17}$ direct inversion of iterative subspace (DIIS) technique to accelerate SCF convergence using, where necessary, a small electron thermal smearing value of $0.005 \mathrm{Ha}$.

Preliminary transition state geometries were obtained using the integrated linear synchronous transit/quadratic synchronous transit (LST/QST) method, ${ }^{18}$ and then subjected to full TS optimization using an eigenvector following algorithm. Where necessary, these geometries were confirmed using intrinsic reaction path (IRP) calculations, based on the nudged elastic band (NEB) algorithm, ${ }_{1}^{19}$ to map the pathways connecting the relevant reactant, transition state and product geometries. All structures identified as stationary points were subjected to frequency analysis, to verify their classification as equilibrium geometries (zero imaginary frequencies) or transition states (one imaginary frequency). The reported energies reflect Gibbs free energy corrections to the total electronic energies at $298.15 \mathrm{~K}$ and include zero-point energy (ZPE) corrections.

\section{Acknowledgements}

The authors thank Sasol Technology Ltd for a bursary (to I.T.S.) and Sasol Technology Ltd, the Technology and Human Resources for Industry Programme (THRIP; Project no. 2642) and Rhodes University for generous financial support. 


\section{References}

1 I.T. Sabbagh and P.T. Kaye, A computational study of Grubbs-type catalysts: structure and application in the degenerate metathesis of ethylene, J. Molec. Struct.: THEOCHEM, 2006, 763, 37-42.

2 I.T. Sabbagh and P.T. Kaye, The regiospecific synthesis of 8-bromocamphor revisited - A DFT computational study, J. Molec. Struct: THEOCHEM, 2007, 847, 32-38.

3 C.R. Eck, R.W. Mills and T. Money, Synthetic route to 8-substituted camphor derivatives, J. Chem Soc., Chem. Commun., 1973, 911-912.

4 C.R. Eck, R.W. Mills and T. Money, A new regiospecific synthesis of 8-bromocamphor, J. Chem. Soc., Perkin Trans. 1, 1975, 251-255.

5 P. Cachia, N. Darby, C.R. Eck and T. Money, Further observations on the bromination of camphor, J. Chem. Soc., Perkin Trans. 1, 1976, 359-362.

6 J.H. Hutchinson. T. Money and S.E. Piper, Ring cleavage of camphor derivatives: formation of chiral synthons for natural product synthesis, Can. J. Chem., 1986, 64, 854-860.

7 Based on a computational technique developed by Collins and Johnson $^{8,9}$ and refined in our group. ${ }^{10}$

8 C.J. Collins and C.K. Johnson, A computer-assisted analysis of the camphor-14c sulfuric acid reaction. Is 3,2-endo hydroxyl shift necessary? J. Am. Chem. Soc., 1973, 95, 4766-4768.

9 C.J. Collins and C.K. Johnson, Algebraic model for the rearrangements of 2-bicyclo[2.2.1] heptyl cations, J. Am. Chem. Soc., 1974, 96, 2514- 2513.

10 K.A. Lobb, unpubl. work.
11 C.A. Bear and J. Trotter, (-)-3,3,4-Trimethyl-1,7-dibromonorbornan2-one, Acta Cryst., 1975, B31, 904.

12 Sabbagh, I.S., Metathesis Catalysts: an Integrated Computational, Mechanistic and Synthetic Study, Ph.D. thesis, Rhodes University, 2005.

13 R. Antkowiak and W.Z. Antkowiak, Structure of some new minor products of 3-substituted camphor bromination. The stereospecificity of camphor methyl group functionalization, Polish J. Chem., 1994, 68, 2297.

14 B. Delley, An all-electron numerical method for solving the local density functional for polyatomic molecules, J. Chem. Phys., 1990, 92, 508-517; B. Delley, Fast calculation of electrostatics in crystals and large molecules, J. Phys. Chem., 1996, 100, 6107-6110. B. Delley, From molecules to solids with the DMol3 approach, J. Chem. Phys., 2000, 113, 7756-7764.

15 J.P. Perdew and Y. Wang, Accurate and simple analytic representation of the electron-gas correlation energy, Phys. Rev. B., 1992,45, 13244-13249.

16 W. Kohn and L.J. Sham, Self-consistent equations including exchange and correlation effects, Phys. Rev., 1965, 140, A1133.

17 P. Pulay, Improved SCF convergence acceleration, J. Comp. Chem., 1982, 3, 556-560.

18 T.A. Halgren and W.N. Lipscomb, The synchronous-transit method for determining reaction pathways and locating molecular transition states, Chem. Phys. Lett., 1977, 49, 225-232.

19 G. Henkelman and H. Jonsson, Improved tangent estimate in the nudged elastic band method for finding minimum energy paths and saddle points, J. Chem. Phys., 2000, 113, 9978-9985. 